\title{
Effects of mixed pulp mill sludges on crop yields and quality
}

\author{
Sari Kinnula ${ }^{1}$, Marjaana Toivonen $^{1,2}$, Helena Soinne ${ }^{3}$, Juuso Joona ${ }^{1}$ and Jukka Kivelä ${ }^{1}$ \\ ${ }^{1}$ Department of Agricultural Sciences, University of Helsinki PO Box 27, Fl-00014 University of Helsinki, Finland \\ ${ }^{2}$ Finnish Environment Institute (SYKE), Biodiversity Centre, Latokartanonkaari 11, FI-00790 Helsinki, Finland \\ ${ }^{3}$ Natural Resources Institute Finland (Luke), Latokartanonkaari 9, FI-00790 Helsinki, Finland \\ e-mail: sari.kinnula@helsinki.fi
}

\begin{abstract}
There is a great need for sustainable fertilisers and soil amendments, as current fertilisation practices negatively affect the environment. Pulp mill sludges (PMS) could provide a means to replace fertilisers made using nonrenewable resources while adding slowly decomposing organic material to the soil and utilising nutrients from the forest industry. This study tested the effects of composted and lime-stabilised mixed PMS (CPMS and LPMS) on wheat (Triticum aestivum) yields and residual effect on oat (Avena sativa) yields in the boreal region. A two-year field experiment included two CPMS and two LPMS treatments all with additional mineral fertilisation, a mineral fertiliser treatment, and a zero-control treatment. All the fertilisers increased yields. There were no differences in crop yields between CPMS, LPMS and mineral fertiliser treatments. However, some quality characteristics and nitrogen $(\mathrm{N})$ uptake were lower with all or some PMS compared with mineral fertilisation. This result suggests that part of the mineral fertilisation for cereals could be replaced by using PMS, but more information on $\mathrm{N}$ mineralisation from sludges is needed.
\end{abstract}

Key words: primary sludge, secondary sludge, organic fertiliser, soil amendment, recycled fertiliser, nutrient recycling

\section{Introduction}

Expansion and intensification of agriculture have caused adverse impacts on the environment (Foley et al. 2005, 2011), including increased greenhouse gas concentrations in the atmosphere (Smith et al. 2014), disturbed nitrogen (N) and phosphorus (P) cycles (Rockström et al. 2009, Steffen et al. 2015), soil degradation and biodiversity loss (Stoate et al. 2001). These problems threaten the capacity of ecosystems to produce food for the growing human population (FAO 2017).

Regarding the productivity of agricultural soils, soil organic matter is crucial. It affects the soil's chemical, biological and physical properties (Matson et al. 1997, Marinari et al. 2000, Bot and Benites 2005) and, consequently, yields (Lal 2004, Oldfield et al. 2019). A decline in soil organic carbon (C) also increases the risk of erosion (Jankauskas et al. 2007, Soinne et al. 2016) and nutrient leaching (Stoate et al. 2001). In most of Europe, soil organic $C$ has been decreasing (Bellamy et al. 2005, Goidts and van Wesemael 2007, Capriel 2013, but see Poeplau et al. 2015). For example, in Finland, the average annual decline in mineral soils has been $0.4 \%$ or $220 \mathrm{~kg} \mathrm{ha}^{-1}$ in recent decades (Heikkinen et al. 2013).

The challenges that food production faces have been proposed to be solved by agroecological, ecological or sustainable intensification, which all aim to increase production with minimised environmental impacts (Wezel et al. 2015). These strategies include increasing the use of recycled organic fertilisers in agriculture in order to restore nutrient cycles and reduce the use of fertilisers made from non-renewable resources. The recycled organic fertilisers can be either of animal or plant origin, such as meat and bone meal (Kivelä et al. 2015) or vinasse (Yang et al. 2013).

One type of recycled organic fertiliser is pulp and paper mill sludges, which are by-products from the forest industry. In Finland, the paper and pulp industry produces $578000 \mathrm{t}$ of sludges yearly, which contains $230 \mathrm{t} \mathrm{P}$ and $1160 \mathrm{t}$ total $\mathrm{N}$, out of which $30 \mathrm{t}$ is soluble N (Marttinen et al. 2017). Currently, most of the sludges are incinerated or landfilled, which is associated with adverse environmental and economic impacts (Monte et al. 2009). From the ecological sustainability point of view, the nutrients should be recycled and not discarded (Marttinen et al. 2017).

The main types of pulp and paper mill waste include primary, secondary, and deinking sludge (Monte et al. 2009). In terms of volume, wastewater treatment sludges, which are produced during the treatment of wastewater, constitute the largest residual waste stream generated by the pulp and paper industry (Monte et al. 2009). These sludges are solid wastes that come from two sources: primary sludge from the primary treatment and biological or secondary sludge from the biological treatment plants (Monte et al. 2009). The characteristics of the sludges vary depending on the production processes used in the pulp and paper making (Gendebien et al. 2001). 


\section{AGRICULTURAL AND FOOD SCIENCE}

S. Kinnula et al. (2020) 29: 276-286

Primary sludge comprises primarily wood fibres and has a high C/N ratio (Vance 2000), and it reflects the composition of wood fibre, the composition being $15-35 \%$ hemicellulose, $40-45 \%$ cellulose and $20-30 \%$ lignin (Camberato et al. 2006). Secondary sludge has higher concentrations of $N$ and $P$ and a lower $C / N$ ratio (Vance 2000). These sludges are generally blended, have a polymer added and are dewatered to a $25-40 \%$ dry solid content (Monte et al. 2009). In general, the sludges are rich in organic matter and contain several plant nutrients, including $N, P$, potassium (K), calcium (Ca), and magnesium (Mg) (Vance 2000, Gendebien et al. 2001). In Finland, hygienisation treatment is required if a fertiliser or soil amendment contains more than $10 \%$ of biosludge, i.e. secondary sludge (the Decree of the Ministry of Agriculture and Forestry on Fertiliser Products 24/11). The sludges can be hygienised and stabilised using methods such as composting or lime stabilisation.

Using pulp and paper mill sludges as fertilisers and soil amendments have been found to have positive environmental effects. Board-mill sludge reduced P losses from conservation-tilled clay soil (Muukkonen et al. 2009). Vinten et al. (1998) reported a reduction in nitrate $\left(\mathrm{NO}_{3}\right)$ leaching after adding paper mill waste to the soil. Kirchmann and Bergström (2003) found that primary paper mill sludge reduced $\mathrm{NO}_{3}$ leaching from agricultural soil. However, Vagstad et al. (2001) found an increase in the residual mineral $\mathrm{N}$ in the soil after sludge application and thus an increased risk of $\mathrm{NO}_{3}$ leaching.

Organic fertilisers and soil amendments also have the potential to increase soil organic C (Freibauer et al. 2004, Kätterer et al. 2011) and contribute to climate change mitigation (Smith et al. 2000, Paustian et al. 2016). Several studies have found an increase in soil organic C after pulp and paper mill sludge addition (Phillips et al. 1997, Rantala et al. 1999, Zibilske et al. 2000, Foley and Cooperband 2002, Chow et al. 2003).

Pulp and paper mill sludges can also have positive effects on soil quality properties. The reported effects include an increase in enzyme activity (Gagnon et al. 2004), soil nutrient level (Sippola et al. 2003, Gagnon et al. 2004), water-holding capacity (Zibilske et al. 2000, Foley and Cooperband 2002, Chow et al. 2003), soil porosity (Phillips et al. 1997, Sippola et al. 2003) and the size of soil aggregates and aggregate stability (Zibilske et al. 2000, Chow et al. 2003, N’Dayegamiye 2006, Price and Voroney 2007), as well as a decrease in soil bulk density (Zibilske et al. 2000, Foley and Cooperband 2002, Chow et al. 2003, Sippola et al. 2003, N'Dayegamiye 2006, Price and Voroney 2007, Rato Nunes et al. 2008) and an improvement in surface water infiltration (Price and Voroney 2007).

The chemical composition of primary, secondary, mixed and deinking sludges and the amount applied varies between studies, which makes comparing different yield results challenging. It also varies between studies if the sludges are applied alone or with additional fertilisers. Some studies have found a decrease in cereal yields after sludge application (Dolar et al. 1972, Bellamy et al. 1995, Aitken et al. 1998, Simard et al. 1998), probably due to $\mathrm{N}$ immobilisation because of a high C/N ratio of the sludges (Bellamy et al. 1995, Mary et al. 1996). In contrast, other studies have reported yield increases (Simard 2001, Vagstad et al. 2001, N’Dayegamiye et al. 2003, Curnoe et al. 2006, N’Dayegamiye 2009, Gagnon et al. 2010, Gagnon and Ziadi 2012, Ziadi et al. 2013) or yields similar to mineral fertilisation (Rantala et al. 1999, Sippola et al. 2003, N’Dayegamiye 2006, Gagnon et al. 2010).

Studies on the effects of lime-stabilised mixed pulp mill sludges (LPMS) on crop yields are scarce, and comparisons on the yield effects of LPMS and composted mixed pulp mill sludges (CPMS) are also lacking. This study tested the effects of LPMS and CPMS on wheat (Triticum aestivum) yields, and the residual effect on oat (Avena sativa) yields, some grain quality characteristics and $\mathrm{N}$ uptake when mineral fertilisers were partly replaced by these types of sludges. The first hypothesis was that part of the fertilisation could be replaced by pulp mill sludges (PMS) without compromising the yield quantity or quality. The second hypothesis was that the effect on yields of CPMS and LPMS is different because of the differences in their chemical composition.

\section{Materials and methods}

\section{Description of the mixed pulp mill sludges}

The experiment included four different types of mixed PMS products (produced by Soilfood Oy, formerly Tyynelän maanparannus Oy), out of which two were CPMS, and two were LPMS. Both CPMS and LPMS came from two different mills in Finland, mill A (Stora Enso Imatra) and mill B (UPM Lappeenranta). The PMS were a mixture of primary and secondary sludge from a pulp mill's wastewater treatment, comprising approximately $70 \%$ primary sludges and $30 \%$ secondary sludges. The static pile composting period was eight weeks to reach hygiene requirements for CPMS. For LPMS, lime stabilisation was performed by mixing burned lime $(\mathrm{CaO})$ and slaked lime $(\mathrm{CaOH})$ 


\section{AGRICULTURAL AND FOOD SCIENCE}

constituting 5\% of PMS mass to raise $\mathrm{pH}$ to 12 for at least two hours according to Finnish fertiliser regulation. The total $\mathrm{C}$ content of the sludges ranged from 30 to $37 \%$ on a dry weight basis, the $\mathrm{C} / \mathrm{N}$ ratio ranged from 22 to 32 , and the $\mathrm{pH}$ ranged from 6.3 to 8.3 (Table 1). The concentration of cadmium (Cd) in sludges from mill B exceeded the maximum permissible $\mathrm{Cd}$ concentration for soil amendments under Finnish legislation, which is $1.5 \mathrm{mg} \mathrm{kg}^{-1} \mathrm{DM}$.

Table 1. Chemical composition of pulp mill sludges and the application rates of pulp mill sludges and nutrients in them in the field experiment, on a dry weight basis

\begin{tabular}{|c|c|c|c|c|}
\hline \multicolumn{5}{|c|}{ Chemical composition of pulp mill sludges } \\
\hline & CPMS A & LPMS A & CPMS B & LPMS B \\
\hline Dry matter (\%) & 48 & 47 & 41 & 50 \\
\hline $\mathrm{pH}_{\mathrm{H} 2 \mathrm{O}}$ & 7.8 & 8.3 & 6.3 & 7.7 \\
\hline C total, \% & 32.9 & 30.4 & 36.6 & 31.2 \\
\hline $\mathrm{N}$ total, $\mathrm{g} \mathrm{kg}^{-1}$ & 12 & 9.5 & 13 & 14 \\
\hline $\mathrm{N}$ soluble, $\mathrm{g} \mathrm{kg}^{-1}$ & 0.69 & 0.63 & 1.60 & 1.10 \\
\hline $\mathrm{C}: \mathrm{N}$ ratio & 27 & 32 & 28 & 22 \\
\hline$P$ total, $\mathrm{mg} \mathrm{kg}^{-1}$ & 2000 & 1900 & 1500 & 2900 \\
\hline $\mathrm{K}, \mathrm{mg} \mathrm{kg}^{-1}$ & 750 & 700 & 280 & 370 \\
\hline $\mathrm{Ca}, \mathrm{mg} \mathrm{kg}^{-1}$ & 45000 & 74000 & 35000 & 95000 \\
\hline $\mathrm{Mn}, \mathrm{mg} \mathrm{kg}^{-1}$ & 1600 & 980 & 1300 & 1800 \\
\hline $\mathrm{Zn}, \mathrm{mg} \mathrm{kg}^{-1}$ & 100 & 84 & 200 & 230 \\
\hline $\mathrm{Cu}, \mathrm{mg} \mathrm{kg}^{-1}$ & 25 & 17 & 15 & 19 \\
\hline $\mathrm{Pb}, \mathrm{mg} \mathrm{kg}^{-1}$ & 8 & 8 & 8 & 8 \\
\hline $\mathrm{Cd}, \mathrm{mg} \mathrm{kg}^{-1}$ & 0.6 & 0.5 & 2 & 2 \\
\hline Organic matter, \% & 74.5 & 68.8 & 83.1 & 71.5 \\
\hline \multicolumn{5}{|c|}{ Application rates of pulp mill sludges and nutrients in them $\left(\mathrm{kg} \mathrm{ha}^{-1}\right)$ in the four PMS treatments of the field experiment } \\
\hline & CPMS A & LPMS A & CPMS B & LPMS B \\
\hline Application rate of PMS & 24864 & 24326 & 17661 & 25324 \\
\hline $\mathrm{N}$ total & 298 & 231 & 230 & 355 \\
\hline N soluble & 17 & 15 & 28 & 28 \\
\hline $\mathrm{P}$ & 50 & 46 & 27 & 73 \\
\hline K & 18.6 & 17.0 & 4.9 & 9.4 \\
\hline $\mathrm{S}$ & 164 & 131 & 136 & 233 \\
\hline B & 0.5 & 0.3 & 0.2 & 0.4 \\
\hline $\mathrm{Mn}$ & 39.8 & 23.8 & 23.0 & 45.6 \\
\hline $\mathrm{Ca}$ & 1119 & 1800 & 618 & 2406 \\
\hline Ctot & 8180 & 7395 & 6464 & 7901 \\
\hline
\end{tabular}

CPMS = composted pulp mill sludge; LPMS = lime-stabilised pulp mill sludge

The total C of the PMS was determined by dry combustion using a Leco CN828 analyser (Leco Corp., St Joseph, MI, USA). Total N was determined by Kjeldahl digestion (Bremner and Mulvaney 1982) and soluble N from 1:5 water extractions according to SFS-EN 13652 (Finnish Standards Association 2002). The total P, K, Ca, manganese (Mn), zinc, copper, lead and cadmium were determined after acid digestion according to SFS-EN ISO 11885:2009 (Finnish Standards Association 2009). pH was determined according to standard SFS-EN 13037 (Finnish Standards Association 2000a), dry matter gravimetrically according to standard SFS-EN 13040 (Finnish Standards Association 2000b) and the organic matter content was determined as the loss upon ignition at $550{ }^{\circ} \mathrm{C}$ for four hours (Finnish Standards Association 2000c). 


\section{AGRICULTURAL AND FOOD SCIENCE}

\section{Field experiment}

The field experiment was established in the research fields of the University of Helsinki, Finland, $\left(60^{\circ} 13^{\prime} 21.9^{\prime \prime} \mathrm{N}\right.$ $25^{\circ} 00^{\prime} 41.2^{\prime \prime} \mathrm{E}$ ) in autumn 2015. During the two cropping seasons (May to September 2016 and 2017), total precipitation was 320.5 and $274.9 \mathrm{~mm}$, respectively. Monthly mean air temperatures $\left({ }^{\circ} \mathrm{C}\right.$ ) during the growing season in 2016 were 14.2, 15.4, 17.8, 16.2 and 13.0, and in 2017, 9.8, 13.7, 16.0, 16.2 and 11.8. The soil type was sandy clay (Aaltonen and Vuorinen 1949), with $\mathrm{pH}_{\mathrm{H} 2 \mathrm{O}}$ (Vuorinen and Mäkitie 1955) of 6.2, 10.8\% organic matter (loss on ignition) and acid ammonium acetate extractable $\mathrm{P} 7.1 \mathrm{mg} \mathrm{l}^{-1}$ and $\mathrm{K}_{265} \mathrm{mg} \mathrm{l}^{-1}$ (pH 4.65; Vuorinen and Mäkitie 1955). According to Finnish guidelines, the status of the soil tests for $\mathrm{P}$ and $\mathrm{K}$ were satisfactory, $\mathrm{Mg}$ poor and $\mathrm{B}$ tolerable.

The field experiment had a factorial design. The main plot factor was stand type with three levels (Appendix 1). The factor levels were sole spring cereal, spring cereal undersown with ryegrass (Lolium perenne), and spring cereal sown with catch crop ryegrass. The main plots of $15 \mathrm{~m} \times 10 \mathrm{~m}$ were randomised in four complete blocks. Stand type, i.e. catch crops and undersown crops were part of the field experiment because their effects on nitrate leaching potential in autumn were also investigated, but these effects are not addressed in this article. Stand type had no effect on the crop yields, and thus this report focuses on the effects of fertilisation. Fertilisation was the subplot factor with six levels: two CPMS and two LPMS treatments with additional mineral fertilisation, a mineral fertiliser treatment, and a zero-control treatment without PMS or mineral fertiliser. The $3 \times 6=18$ treatments were factorial combinations of the two factors, and these were arranged by randomising each fertilisation within each main plot to subplots of $2.2 \mathrm{~m} \times 10.0 \mathrm{~m}$. The experiment was run over two successive growing seasons: in the first season in 2016, wheat, variety 'Anniina' (Boreal Plant Breeding Ltd, Jokioinen, Finland), was grown, and in the second season in 2017, oat, variety 'Obelix' (Saatzucht Bauer GmbH \& Co. KG, Obertraubling, Germany), was grown. Oat was resown because the first sowing did not sprout evenly (Appendix 1).

The quantity of PMS applied ranged from 17.7 to $25.3 \mathrm{t} \mathrm{ha}^{-1}$ on a dry weight basis (Table 1). The application rates of PMS were based on the maximum amount of soluble $\mathrm{N}$ allowed to be applied in the autumn in Finland (30 kg ha-1 N). Soluble $\mathrm{N}$ applied in sludge $A$ treatments were 15 and $17 \mathrm{~kg} \mathrm{ha}^{-1}$ (LPMS and CPMS, respectively) and in sludge $B$ treatments, around $28 \mathrm{~kg} \mathrm{ha}^{-1}$ (Table 1). The lower quantity of applied soluble $\mathrm{N}$ than planned was because the exact nutrient content of the sludges was known only after the application of the sludges. Due to the varying total $\mathrm{N}$ content of the sludges, the total $\mathrm{N}$ applied ranged considerably (Table 1). The amount of other nutrients applied from the mixed PMS also ranged widely (Table 1). The PMS were applied only once in September 2015. They were first spread on the soil surface and then mixed into the upper $10 \mathrm{~cm}$ of soil with a disc cultivator. No PMS were added in 2016 or 2017. The 2017 season of oat was included for detecting possible residual yield effects of the PMS applications of autumn 2015.

All PMS treatments received $250 \mathrm{~kg} \mathrm{ha}^{-1}$ additional mineral fertiliser (50 kg N ha-1) in spring 2016 and $400 \mathrm{~kg} \mathrm{ha}^{-1}$ in spring 2017 (80 kg N ha-1). Mineral fertilisation treatment received $400 \mathrm{~kg} \mathrm{ha}^{-1}\left(80 \mathrm{~kg} \mathrm{~N} \mathrm{ha}^{-1}\right.$ ) in 2016 and 400 $\mathrm{kg} \mathrm{ha}^{-1}\left(80 \mathrm{~kg} \mathrm{~N} \mathrm{ha}^{-1}\right)$ in 2017. The mineral fertiliser used for all fertilisation treatments was Kevätviljan Hiven $\mathrm{Y}$, N-P-K:20-3-8 (Kemira GrowHow, Helsinki, Finland). Ryegrass from undersown and catch crop plots were not harvested but ploughed to the soil. Herbicides were applied in both years according to specific crop recommendations.

The yields were harvested from a $12 \mathrm{~m}^{2}$ area from each plot with a plot combine harvester and converted into yields per hectare at $14 \%$ moisture content. Grain quality characteristics, which were hectolitre weight, 1000-grain weight, starch, and crude protein, were analysed from 2016 wheat yields. Hectolitre weight was analysed with a Grain Analyser (DICKEY-john GAC 2000, DICKEY-john Corp., Auburn, IL, USA) and 1000-grain weight with a Seed counter (Pfeuffer Contador, Pfeuffer $\mathrm{GmbH}$, Kitzingen, Germany). For starch and crude protein, replicates were pooled, and only one grain sample for each stand type fertilisation treatment combination was analysed. Starch and crude protein were determined with near-infrared spectroscopy according to standard SFS-EN ISO 12099 (Finnish Standards Association 2010). Grain N concentration for wheat was calculated from crude protein concentration (Equation 1).

Grain N concentration (\%) = Crude protein (\%)/a

where $a$ is a coefficient of 5.7 for wheat (Sosulski and Imafidon 1990).

$\mathrm{N}$ uptake was calculated as uptake in harvested grain (Equation 2).

$N$ uptake $\left(\mathrm{kg} \mathrm{ha}^{-1}\right)=$ Crude protein $(\%) / a \times$ yield $\left(\mathrm{kg} \mathrm{ha}^{-1}\right) \times 0.86 / 100(\%)$ 
where $a$ is a coefficient as in [1]. A coefficient of 0.86 was used to convert the grain yields from $14 \%$ moisture content to $100 \%$ dry matter content.

\section{Statistical analyses}

To analyse the effects of fertiliser treatments on yield, analysis of variance (ANOVA) was performed using the GLM Univariate procedure of SPSS statistical software version 25 (IBM, Armonk, NY, USA). For the amount of yield, hectolitre weight, and 1000-grain weight, the analysis followed a split-plot ANOVA with stand type as the main plot factor and fertilisation treatment as the subplot factor. For crude protein concentration, starch concentration and $\mathrm{N}$ uptake, which were based on one analysed grain sample for each stand type fertilisation treatment combination, a regular one-way ANOVA was performed to compare fertilisation treatments. Tukey's post hoc pairwise comparisons were done to compare each fertilisation treatment with one another. Treatment effects with probability values above 0.05 were considered non-significant.

\section{Results}

\section{Wheat and oat yields}

Stand type, i.e. catch crops and undersown crops (the main plot factor) had no effect on the crop yields, and thus this report focuses on the effects of fertilisation treatments (the subplot factor). Wheat yields in 2016 ranged from 2358 to $3170 \mathrm{~kg} \mathrm{ha}^{-1}$ and oat yields in 2017 from 6425 to $7876 \mathrm{~kg} \mathrm{ha}^{-1}$ (Fig. 1).
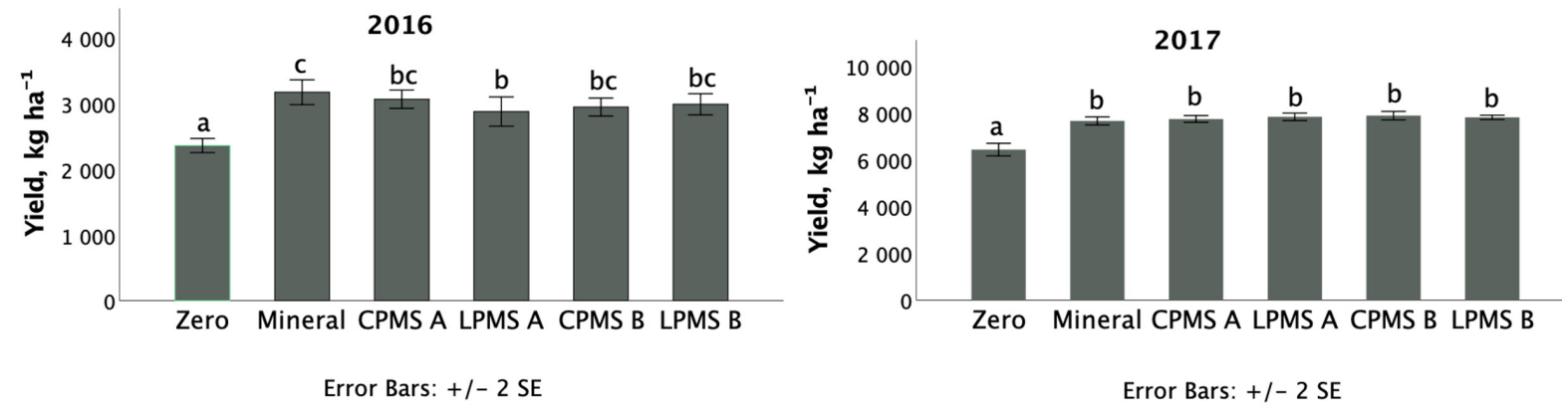

Fig. 1. Wheat yields in 2016 and oat yields in 2017 ( $\mathrm{kg} \mathrm{ha}^{-1}$ at $14 \%$ moisture content) in treatments fertilised by pulp mill sludges (PMS), by mineral fertilisers, or when left unfertilised. Statistically significant differences between the treatments are indicated by different letters above the bars $(p<0.05$, Tukey's test). Error bars: \pm standard error (SE). CPMS $=$ composted pulp mill sludge, LPMS = lime-stabilised pulp mill sludge

In 2016, the first year after sludge application, all fertiliser treatments gave higher wheat yields than the zerocontrol treatment (Fig. 1, Appendix 2). There was no significant difference in wheat yields between the PMS treatments or between the PMS and the mineral fertiliser treatment, except for LPMS A, which produced a lower wheat yield than the mineral treatment (Fig. 1, Appendix 2).

In 2017, when all four PMS treatments and the mineral fertiliser treatment were given mineral fertilisation, there were no significant differences in oat yields between any of the fertilisation treatments (Fig. 1, Appendix 2). All fertiliser treatments gave higher oat yields than the zero-control treatment (Fig. 1, Appendix 2).

\section{Grain quality and nitrogen uptake}

There were no differences in any of the grain quality characteristics between any of the four different types of PMS (Table 2). Crude protein and N concentrations were lower with CPMS A and CPMS B sludges compared with the mineral fertilisation but did not differ from the zero-control treatment (Table 2). Crude protein and $\mathrm{N}$ concentrations were higher with LPMS A and LPMS B sludge compared with the zero-control treatment but did not differ from the mineral fertilisation (Table 2). N uptake was lower with both types of LPMS and CPMS B compared with the mineral fertilisation, and with the zero-control treatment compared with all other fertilisation treatments (Table 2). 
Table 2. Results of grain quality characteristics and $\mathrm{N}$ uptake for wheat in 2016 and hectolitre weight for oat in 2017. The results are given on a dry weight basis. Letters after the values denote within-column significant differences $(p<0.05$, Tukey's test).

\begin{tabular}{lccccccc}
\hline $\begin{array}{c}\text { Fertilisation } \\
\text { treatment }\end{array}$ & $\begin{array}{c}\text { Crude protein } \\
\%\end{array}$ & $\begin{array}{c}\mathrm{N} \\
\%\end{array}$ & $\begin{array}{c}\text { Starch } \\
\%\end{array}$ & $\begin{array}{c}\text { 1000-grain weight } \\
\mathrm{g}\end{array}$ & $\begin{array}{c}\mathrm{N} \text { uptake } \\
\mathrm{kg} \mathrm{ha}^{-1}\end{array}$ & $\begin{array}{c}\text { Hectolitre weight } \\
\mathrm{kg} \mathrm{hl}^{-1}, 2016\end{array}$ & $\begin{array}{c}\text { Hectolitre weight } \\
\mathrm{kg} \mathrm{hl}^{-1}, 2017\end{array}$ \\
\hline Zero-control & $14.2 \mathrm{~b}$ & $2.49 \mathrm{~b}$ & $65.8 \mathrm{a}$ & $26.3 \mathrm{~b}$ & $50.3 \mathrm{~b}$ & $80.2 \mathrm{~b}$ & $54.5 \mathrm{~b}$ \\
Mineral & $15.0 \mathrm{c}$ & $2.63 \mathrm{c}$ & $65.0 \mathrm{a}$ & $28.8 \mathrm{c}$ & $71.6 \mathrm{c}$ & $81.2 \mathrm{a}$ & $55.2 \mathrm{ab}$ \\
CPMS A & $14.5 \mathrm{ab}$ & $2.54 \mathrm{ab}$ & $65.7 \mathrm{a}$ & $27.9 \mathrm{a}$ & $66.8 \mathrm{ac}$ & $80.9 \mathrm{ab}$ & $55.4 \mathrm{ab}$ \\
LPMS A & $14.7 \mathrm{ac}$ & $2.57 \mathrm{ac}$ & $65.3 \mathrm{a}$ & $27.6 \mathrm{a}$ & $63.6 \mathrm{a}$ & $80.8 \mathrm{ab}$ & $55.7 \mathrm{a}$ \\
CPMS B & $14.4 \mathrm{ab}$ & $2.53 \mathrm{ab}$ & $65.7 \mathrm{a}$ & $27.9 \mathrm{a}$ & $64.1 \mathrm{a}$ & $81.2 \mathrm{a}$ & $55.4 \mathrm{ab}$ \\
LPMS B & $14.8 \mathrm{ac}$ & $2.60 \mathrm{ac}$ & $65.3 \mathrm{a}$ & $27.9 \mathrm{a}$ & $66.7 \mathrm{a}$ & $80.9 \mathrm{ab}$ & $55.5 \mathrm{ab}$ \\
\hline
\end{tabular}

CPMS = composted pulp mill sludge; LPMS = lime-stabilised pulp mill sludge

The 1000-grain weight was lower with all the other fertilisation treatments compared with the mineral fertilisation, and all four types of PMS and mineral fertilisation gave higher 1000-grain yields compared with the zerocontrol treatment (Table 2). There were no significant differences in wheat grain starch concentration between different fertilisation treatments (Table 2).

In 2016, the hectolitre weight was higher with CPMS B and mineral fertilisation compared with zero fertilisation (Table 2). In 2017, LPMS A gave a higher hectolitre weight compared with zero fertilisation (Table 2). No other significant differences were detected in either of the years in hectolitre weights (Table 2).

\section{Discussion}

\section{Yields}

Wheat yields achieved in the field experiment with composted and lime-stabilised mixed pulp mill sludges with additional mineral fertilisation were higher than from non-fertilised plots, but in contrast to our hypothesis, showed no differences when compared with each other. Pulp mill sludges contain somewhat soluble $\mathrm{N}$ directly available to the plants. However, the decomposition of organic matter with a high $\mathrm{C} / \mathrm{N}$ ratio may initially result in immobilisation of $\mathrm{N}$ (Mary et al. 1996). The yields in the field experiment were as good as the yields achieved with mineral fertilisation (same amount of soluble $\mathrm{N}$ ), except with lime-stabilised sludge $\mathrm{A}$ with the highest $\mathrm{C} / \mathrm{N}$ ratio of 32. Previously Vagstad et al. (2001) reported sludge types with a C/N ratio of around 30 to give mainly negative yield responses, while sludge, with a $\mathrm{C} / \mathrm{N}$ ratio of 23 , gave a significant yield increase in the year following sludge application. However, in our experiment, the sludge with the highest $\mathrm{C} / \mathrm{N}$ ratio also received less soluble $\mathrm{N}$ than the other lime-stabilised pulp sludge treatment, which may also explain the lower yields.

All treatments received mineral fertilisation, but in pulp mill sludges, part of the $\mathrm{N}$ was assumed to originate from the soluble $\mathrm{N}$ pool in the sludges. In the first growing season after the autumn applications, the sludge treatments received $30 \mathrm{~g} \mathrm{ha}^{-1}$ less mineral fertilisation, but three out of four of the sludges resulted in yields in 2016 similar to those achieved with mineral fertilisation only. This suggests that pulp mill sludges have the potential to be used to replace part of the mineral fertilisation. However, the small yield increase gained with $80 \mathrm{~kg} \mathrm{ha}^{-1} \mathrm{~N}$ fertilisation compared with the non-fertilised control leaves room for speculation that something other than $\mathrm{N}$ availability restricted the yield formation. If mineral fertilisation of only $50 \mathrm{~kg} \mathrm{ha}^{-1}$ could produce the yields harvested in 2016, the $\mathrm{N}$ in pulp mill sludges would not have contributed to yield formation, and therefore we cannot say for sure that pulp mill sludges can be used to replace part of the mineral fertilisation. In addition, it is important to note that replacing mineral $\mathrm{N}$ fertilisation completely with large applications of pulp mill sludges can have an adverse effect on the environment due to slow mineralisation of $\mathrm{N}$, timing of which is not optimal for crop needs.The effects of sludges on yields may also originate from other than direct fertilisation effects. In Finland, mineral soils with $\mathrm{pH}$ generally of 5.5-6.0 benefit from liming as the optimal pH would be 6.0-6.5 (Lemola et al. 2018). The $\mathrm{pH}$ of lime-stabilised sludges is higher than 7, and when applied in acidic or slightly acidic soil could increase the soil pH. Furthermore, mixed pulp mill sludges contain a considerable amount of $\mathrm{C}$, thereby having the potential to increase soil organic matter (Phillips et al. 1997, Rantala et al. 1999, Zibilske et al. 2000, Foley and Cooperband 2002, Chow et al. 2003), which in turn may result in improved structure or water-holding capacity in low organic matter soils and thus enhance the productivity of the soil. In fact, for an experimental field with C\% as low as 1.5 , Vagstad et al. (2001) detected that while similarly fertilised, both lime-stabilised and composted sludge amended plots resulted in similar or higher yields than a plot that received only mineral fertilisation. If the improved soil 


\section{AGRICULTURAL AND FOOD SCIENCE}

productivity originates from the increased organic matter it will likely last longer than just one growing season and reported results show that onetime addition of pulp mill sludges may have positive effects on yields also in the following years (residual effect) (Aitken et al. 1998, Simard 2001, N'Dayegamiye et al. 2003, N'Dayegamiye 2006). However, in the second growing season in our field experiment, oat yields from plots treated with pulp mill sludges were similar to those achieved from plots with only mineral fertilisation, which result is in accordance with Sippola et al. (2003). Our experimental field had a C\% higher than 6, and therefore it was unlikely that organic amendments like pulp mill sludges would have a residual effect on soil structural properties or water retention capacity that would have impacted soil productivity.

\section{Nitrogen uptake}

$\mathrm{N}$ uptake was lower with one composted (CPMS B) and both types of lime-stabilised sludges when compared with mineral fertilisation, which is similar to what Sippola et al. (2003) found for some of the tested composted pulp and paper mill sludges. Lower $\mathrm{N}$ uptake for the pulp mill sludges suggests that although the amount of soluble $\mathrm{N}$ was adjusted to be close to that of the mineral fertilisation, it was not completely available for the plants, and the possible mineralisation of organic $\mathrm{N}$ was not optimally timed for crop needs. N'Dayegamiye (2006), in contrast, achieved as good $\mathrm{N}$ uptake with sludges with additional fertilisation as with only mineral fertilisation. In our experiment, only CPMS $\mathrm{A}$ with the second-lowest $\mathrm{C} / \mathrm{N}$ ratio resulted in $\mathrm{N}$ uptake as high as with mineral fertilisation. Only lime-stabilised pulp mill sludge $B$ had a lower $\mathrm{C} / \mathrm{N}$ ratio and nearly the same $\mathrm{N}$ uptake as CPMS $\mathrm{A}$, but it was found to differ statistically from the mineral fertilisation treatment. The lower $\mathrm{C} / \mathrm{N}$ ratio may explain the higher $\mathrm{N}$ uptake compared with other pulp mill sludges, as immobilisation is more likely in organic masses with a high C/N ratio (Mary et al. 1996). Higher $\mathrm{N}$ uptake may also be explained by the liming effect, as liming increases the $\mathrm{N}$ uptake and grain N concentration (Lyngstad 1992, Soon and Arshad 2005).

\section{Grain quality}

Equally high hectolitre weights achieved with pulp mill sludges with additional mineral fertilisation and only mineral fertilisation are consistent with the findings of N'Dayegamiye (2006) but in contrast with N'Dayegamiye et al. (2003). Previous studies have reported variable effects of pulp and paper mill sludges with additional mineral fertilisation on grain $\mathrm{N}$ concentration compared to mineral or zero fertilisation (Simard et al. 1998, Vagstad et al. 2001, Curnoe et al. 2006, Ziadi et al. 2013), suggesting that the effects are sensitive to the chemical composition of the sludges and the amounts applied. In our experiment, lime-stabilised pulp mill sludges with additional mineral fertilisation resulted in similar crude protein and grain $\mathrm{N}$ concentration as mineral fertilisation. However, composted pulp mill sludges resulted in significantly lower crude protein and grain $\mathrm{N}$ concentrations compared with the mineral fertilisation. Grain protein concentration is affected by N availability (Peltonen and Virtanen 1994, Wooding et al. 2000, Doltra et al. 2011), which implies that in composted pulp mill sludges there might not have been enough available $\mathrm{N}$ for plants to use during critical stages of crop yield formation. All four types of mixed pulp mill sludges with additional mineral fertilisation resulted in lower 1000-grain weight compared with mineral fertilisation, which might be explained by inadequate nitrogen availability. However, low $\mathrm{N}$ rates do not seem to affect 1000-grain weight in Finnish conditions in general (Valkama et al. 2013, but see Esala and Larpes 1986).

\section{Conclusions}

Recycling nutrients from the forest industry to agriculture has the potential to reduce the use of primary fertilisers and associated adverse environmental effects. Our results suggest that part of the mineral nitrogen fertilisation for spring cereals can be replaced by using mixed pulp mill sludges applied in the previous autumn and that when applied into soil high in $\mathrm{C}$, the sludges have no residual effect in the second year following the application. The use of composted pulp mill sludges resulted in lower grain $\mathrm{N}$ content, suggesting that the timing of $\mathrm{N}$ availability was not optimal. Further experiments are needed to investigate the mineralisation of nitrogen from the pulp mill sludges in more detail, and to compare the effects of the sludges on crop yields with and without additional mineral nitrogen. 


\section{Acknowledgements}

We thank Juha Helenius and two anonymous reviewers for their valuable comments to the manuscript. We also thank Markku Tykkyläinen who helped with the establishment and management of the field experiment. This work was supported by Maa- ja vesitekniikan tuki ry. association, Olvi foundation, Finnish Funding Agency for Technology and Innovation (Tekes, now Business Finland) as a part of the NSPPulp project, Stora Enso Oyj and UPM Oyj.

\section{References}

Aaltonen, V.T. \& Vuorinen, J. 1949. Maaperäsanaston ja maalajien luokituksen tarkistus v. 1949. Maataloustieteellinen aikakauskirja 21:37-66. https://doi.org/10.23986/afsci.71269

Aitken, M., Evans, B. \& Lewis, J.G. 1998. Effect of applying paper mill sludge to arable land on soil fertility and crop yields. Soil Use and Management 14: 215-222. https://doi.org/10.1111/j.1475-2743.1998.tb00153.x

Bellamy, K., Chong, C. \& Cline, R. 1995. Paper sludge utilization in agriculture and container nursery culture. Journal of Environmental Quality 24: 1074-1082. https://doi.org/10.2134/jeq1995.00472425002400060005x

Bellamy, P.H., Loveland, P.J., Bradley, R.I., Lark, R.M. \& Kirk, G.J. 2005. Carbon losses from all soils across England and Wales 19782003. Nature 437: 245-248. https://doi.org/10.1038/nature04038

Bot, A. \& Benites, J. 2005. The importance of soil organic matter: key to drought-resistant soil and sustained food production. FAO Soils Bulletin 80. Food and Agriculture Organization of the United Nations, Rome. 78 p.

Bremner, J.M. \& Mulvaney, C.S. 1982 Nitrogen-Total. Methods of Soil Analysis. Part 2. Chemical and Microbiological Properties. American Society of Agronomy, Soil Science Society of America. $1572 \mathrm{p}$.

Camberato, J., Gagnon, B., Angers, D., Chantigny, M. \& Pan, W. 2006. Pulp and paper mill by-products as soil amendments and plant nutrient sources. Canadian Journal of Soil Science 86: 641-653. https://doi.org/10.4141/S05-120

Capriel, P. 2013. Trends in organic carbon and nitrogen contents in agricultural soils in Bavaria (south Germany) between 1986 and 2007. European Journal of Soil Science 64: 445-454. https://doi.org/10.1111/ejss.12054

Chow, T.L., Rees, H.W., Fahmy, S.H. \& Monteith, J. 2003. Effects of pulp fibre on soil physical properties and soil erosion under simulated rainfall. Canadian Journal of Soil Science 83: 109-119. https://doi.org/10.4141/S02-009

Curnoe, W.E., Irving, D.C., Dow, C.B., Velema, G. \& Unc, A. 2006. Effect of Spring Application of a Paper Mill Soil Conditioner on Corn Yield. Agronomy Journal 98: 423-429.https://doi.org/10.2134/agronj2005.0041

Dolar, S.G., Boyle, J.R. \& Keeney, D.R. 1972. Paper mill sludge disposal on soils: effects on the yield and mineral nutrition of oats (Avena sativa L.). Journal of Environmental Quality 1: 405-409. https://doi.org/10.2134/jeq1972.00472425000100040015x

Doltra, J., Lægdsmand, M. \& Olesen, J.E. 2011. Cereal yield and quality as affected by nitrogen availability in organic and conventional arable crop rotations: A combined modeling and experimental approach. European Journal of Agronomy 34:83-95. https://doi.org/10.1016/j.eja.2010.11.002

Esala, M. \& Larpes, G. 1986. Effect of the placement technique and amount of fertilizer on spring wheat and barley grown on clay soils II. Effect of the quality and mineral contents of grain yield. Annales Agriculturae Fenniae 25: 169-175.

FAO 2017. The future of food and agriculture - Trends and challenges. Rome. http://www.fao.org/3/a-i6583e.pdf

Finnish Standards Association 2000a. SFS-EN 13037, Soil improvers and growing media. Determination of pH. Finnish Standards Association SFS. Finnish Environment Institute, Helsinki.

Finnish Standards Association 2000b. SFS-EN 13040, Soil Improvers and Growing Media. Sample Preparation for Chemical and Physical Tests, Determination of Dry Matter Content, Moisture Content and Laboratory Compacted Bulk Density. Finnish Standards Association (SFS), Helsinki, Finland.

Finnish Standards Association 2000c. SFS-EN 13039, Soil improvers and growing media. Determination of organic matter content and ash. Finnish Standards Association SFS, Helsinki, Finland.

Finnish Standards Association 2002. SFS-EN 13652, Soil improvers and growing media. Extraction of water soluble extractable nutrients and elements. Finnish Standards Association, Helsinki, Finland.

Finnish Standards Association 2009. SFS-EN ISO 11885, Water Quality. Determination of Selected Elements by Inductively Coupled Plasma Optical Emission Spectrometry (ICP-OES). Finnish Standards Association, Helsinki, Finland.

Finnish Standards Association 2010. SFS-EN ISO 12099, Animal feeding stuffs, cereals and milled cereal products - Guidelines for the application of near infrared spectrometry. Finnish Standards Association, Helsinki, Finland.

Foley, B.J. \& Cooperband, L.R. 2002. Paper mill residuals and compost effects on soil carbon and physical properties. Journal of Environmental Quality 31: 2086-2095. https://doi.org/10.2134/jeq2002.2086

Foley, J.A., Defries, R., Asner, G.P., Barford, C., Bonan, G., Carpenter, S.R., Chapin, F.S., Coe, M.T., Daily, G.C., Gibbs, H.K., Helkowski, J.H., Holloway, T., Howard, E.A., Kucharik, C.J., Monfreda, C., Patz, J.A., Prentice, I.C., Ramankutty, N. \& Snyder, P.K. 2005. Global consequences of land use. Science 309: 570-574. https://doi.org/10.1126/science.1111772

Foley, J.A., Ramankutty, N., Brauman, K.A., Cassidy, E.S., Gerber, J.S., Johnston, M., Mueller, N.D., O'Connell, C., Ray, D.K., West, P.C., Balzer, C., Bennett, E.M., Carpenter, S.R., Hill, J., Monfreda, C., Polasky, S., Rockström, J., Sheehan, J., Siebert, S., Tilman, D. \& Zaks, D.P.M. 2011. Solutions for a cultivated planet. Nature 478: 337-342. https://doi.org/10.1038/nature10452

Freibauer, A., Rounsevell, M.D.A., Smith, P. \& Verhagen, J. 2004. Carbon sequestration in the agricultural soils of Europe. Geoderma 122: 1-23. https://doi.org/10.1016/j.geoderma.2004.01.021 
Gagnon, B., Simard, R.R., Lalande, R. \& Lafond, J. 2004. Improvement of soil properties and fruit yield of native lowbush blueberry by papermill sludge addition. Canadian Journal of Soil Science 83: 1-9. https://doi.org/10.4141/S02-011

Gagnon, B. \& Ziadi, N. 2012. Papermill biosolids and alkaline residuals affect crop yield and soil properties over nine years of continuous application. Canadian Journal of Soil Science 92: 917-930. https://doi.org/10.4141/cjss2012-026

Gagnon, B., Ziadi, N., Côté, C. \& Foisy, M. 2010. Environmental impact of repeated applications of combined paper mill biosolids in silage corn production. Canadian Journal of Soil Science 90: 215-227. https://doi.org/10.4141/CJSS09055

Gendebien, A., Ferguson, R., Horth, H., Sullivan, M., Davis, R., Brunet, H., Dalimier, F., Landrea, B., Krack, D., Perot, J. \& Orsi, C. 2001. Survey of Wastes spread to Land. Final Report of DG Environment Study Contract B4-3040/99/110194/MAR /E3.

Goidts, E. \& van Wesemael, B. 2007. Regional assessment of soil organic carbon changes under agriculture in Southern Belgium (1955-2005). Geoderma 141: 341-354. https://doi.org/10.1016/j.geoderma.2007.06.013

Heikkinen, J., Ketoja, E., Nuutinen, V. \& Regina, K. 2013. Declining trend of carbon in Finnish cropland soils in 1974-2009. Global Change Biology 19: 1456-1469. https://doi.org/10.1111/gcb.12137

Jankauskas, B., Jankauskiene, G. \& Fullen, M.A. 2007. Relationships between soil organic matter content and soil erosion severity in Albeluvisols of the Zemaiciai Uplands. Ekologija 53: 21-28.

Kätterer, T., Bolinder, Ma., Andrén, O., Kirchmann, H. \& Menichetti, L. 2011. Roots contribute more to refractory soil organic matter than above-ground crop residues, as revealed by a long-term field experiment. Agriculture Ecosystems \& Environment 141: 184-192. https://doi.org/10.1016/j.agee.2011.02.029

Kirchmann, H. \& Bergström, L. 2003. Use of paper-mill wastes on agricultural soils: Is this a way to reduce nitrate leaching? Acta agriculturae Scandinavica Section B. Soil \& Plant Science 53:56-63. https://doi.org/10.1080/09064710310003925

Kivelä, J., Chen, L., Muurinen, S., Kivijärvi, P., Hintikainen, V. \& Helenius, J. 2015. Effects of meat bone meal as fertilizer on yield and quality of sugar beet and carrot. Agricultural and Food Science 24: 8-83. https://doi.org/10.23986/afsci.8587

Lal, R. 2004. Soil carbon sequestration impacts on global climate change and food security. Science 304: 1623-1627. https://doi.org/10.1126/science.1097396

Lemola, R., Uusitalo, R., Hyväluoma, J., Sarvi, M. \& Turtola, E. 2018. Suomen peltojen maalajit, multavuus ja fosforipitoisuus: Vuodet 1996-2000 ja 2005-2009. Luonnonvarakeskus (Luke), Helsinki. (in Finnish).

Lyngstad, I. 1992. Effect of liming on mineralization of soil-nitrogen as measured by plant uptake and nitrogen released during incubation. Plant and Soil 144: 247-253. https://doi.org/10.1007/BF00012881

Marinari, S., Masciandaro, G., Ceccanti, B. \& Grego, S. 2000. Influence of organic and mineral fertilisers on soil biological and physical properties. Bioresource Technology 72: 9-17. https://doi.org/10.1016/S0960-8524(99)00094-2

Marttinen, S., Venelampi, O., Iho, A., Koikkalainen, K., Lehtonen, E., Luostarinen, S., Rasa, K., Sarvi, M., Tampio, E., Turtola, E., Ylivainio, K., Grönroos, J., Kauppila, J., Koskiaho, J., Valve, H., Laine-Ylijoki, J., Lantto, R., Oasmaa, A. \& zu Castell-Rüdenhausen, M. 2017. Towards a breakthrough in nutrient recycling: State-of-the-art and recommendations for developing policy instruments in Finland. Natural resources and bioeconomy studies 26/2018. Natural Resources Institute Finland, Helsinki. 54 p.

Mary, B., Recous, S., Darwis, D. \& Robin, D. 1996. Interaction between decomposition of plant residues and N cycling in soil. Plant and Soil 181: 71-82. https://doi.org/10.1007/BF00011294

Matson, P., Parton, W., Power, A. \& Swift, M. 1997. Agricultural intensification and ecosystem properties. Science 277: 504-509. https://doi.org/10.1126/science.277.5325.504

Monte, M.C., Fuente, E., Blanco, A. \& Negro, C. 2009. Waste management from pulp and paper production in the European Union. Waste Management 29: 293-308. https://doi.org/10.1016/j.wasman.2008.02.002

Muukkonen, P., Hartikainen, H. \& Alakukku, L. 2009. Boardmill sludge reduces phosphorus losses from conservation-tilled clay soil. Soil and Tillage Research 104: 285-291. https://doi.org/10.1016/j.still.2009.03.003

N'Dayegamiye, A. 2006. Mixed paper mill sludge effects on corn yield, nitrogen efficiency, and soil properties. Agronomy Journal 98: 1471-1478. https://doi.org/10.2134/agronj2005.0339

N'Dayegamiye, A., Huard, S. \& Thibault, Y. 2003. Influence of paper mill sludges on corn yields and N recovery. Canadian Journal of Soil Science 83: 497-505. https://doi.org/10.4141/S02-077

N'Dayegamiye, A. 2009. Soil properties and crop yields in response to mixed paper mill sludges, dairy cattle manure, and inorganic fertilizer application. Agronomy Journal 101: 826-835. https://doi.org/10.2134/agronj2008.0170x

Oldfield, E.E., Bradford, M.A. \& Wood, S.A. 2019. Global meta-analysis of the relationship between soil organic matter and crop yields. Soil 5: 15-32. https://doi.org/10.5194/soil-5-15-2019

Paustian, K., Lehmann, J., Ogle, S., Reay, D., Robertson, G.P. \& Smith, P. 2016. Climate-Smart Soils. Nature 532: 49-57. https://doi.org/10.1038/nature17174

Phillips, V.R., Kirkpatrick, N., Scotford, I.M., White, R.P. \& Burton, R.G.O. 1997. The use of paper-mill sludges on agricultural land. Bioresource technology 60: 73-80. https://doi.org/10.1016/S0960-8524(97)00006-0

Peltonen, J. \& Virtanen, A. 1994. Effect of nitrogen fertilizers differing in release characteristics on the quality of storage proteins in wheat. Cereal Chemistry 71: 1-5.

Price, G.W. \& Voroney, R.P. 2007. Papermill biosolids effect on soil physical and chemical properties. Journal of Environmental Quality 36: 1704-1714. https://doi.org/10.2134/jeq2007.0043

Poeplau, C., Bolinder, M.A., Eriksson, J., Lundblad, M. \& Kätterer, T. 2015. Positive trends in organic carbon storage in Swedish agricultural soils due to unexpected socioeconomic drivers. Biogeosciences 12: 3241-3251. https://doi.org/10.5194/bg-12-3241-2015 
Rantala, P.R., Vaajasaari, K., Juvonen, R., Schultz, E., Joutti, A. \& Mäkelä-Kurtto, R. 1999. Composting of forest industry wastewater sludges for agriculture use. Water Science and Technology 40: 187-194. https://doi.org/10.2166/wst.1999.0711

Rato Nunes, J., Cabral, F.A. \& López-Piñeiro, A. 2008. Short-term effects on soil properties and wheat production from secondary paper sludge application on two Mediterranean agricultural soils. Bioresource Technology 99: 4935-4942. https://doi.org/10.1016/j.biortech.2007.09.016

Rockström, J., Steffen, W., Noone, K., Persson, Å.F., Chapin III, S., Lambin, E., Lenton, T.M., Scheffer, M., Folke, C., Schellnhuber H., Nykvist, B., De Wit, C.A., Hughes, T., van der Leeuw, S., Rodhe, H., Sörlin, S., Snyder, P.K., Costanza, R., Svedin, U., Falkenmark M., Karlberg, L., Corell, R.W., Fabry, V.J., Hansen, J., Walker, B., Liverman, D., Richardson, K., Crutzen, P. \& Foley, J. 2009. Planetary boundaries: exploring the safe operating space for humanity. Ecology and Society 14: 32. https://doi.org/10.5751/ES-03180-140232

Simard, R.R. 2001. Combined primary/secondary papermill sludge as a nitrogen source in a cabbage-sweet corn cropping sequence. Canadian Journal of Soil Science 81: 1-10. https://doi.org/10.4141/S00-026

Simard, R.R., Baziramakenga, R.S., Yelle, S. \& Coulombe, J. 1998. Effects of De-Inking Paper Sludges on Soil Properties and Crop Yields. Canadian Journal of Soil Science 788: 689-697. https://doi.org/10.4141/S98-003

Sippola, J., Mäkelä-Kurtto, R. \& Rantala, P.-R. 2003. Effects of Composted Pulp and Paper Industry Wastewater Treatment Residuals on Soil Properties And Cereal Yield. Compost Science \& Utilization 11: 228-237. https://doi.org/10.1080/1065657X.2003.10702131

Smith, P., Powlson, D.S., Smith, J.U., Falloon, P. \& Coleman, K. 2000. Meeting Europe's climate change commitments: quantitative estimates of the potential for carbon mitigation by agriculture. Global Change Biology 6: 525-539. https://doi.org/10.1046/ j.1365-2486.2000.00331.x

Smith P., Bustamante, M., Ahammad, H., Clark, H., Dong, H., Elsiddig, E.A., Haberl, H., Harper, R., House, J., Jafari, M., Masera O., Mbow, C., Ravindranath, N.H., Rice, C.W., Robledo Abad, C., Romanovskaya, A., Sperling, F. \& Tubiello, F. 2014. Agriculture, Forestry and Other Land Use (AFOLU). In: Climate Change 2014: Mitigation of Climate Change. Contribution of Working Group III to the Fifth Assessment Report of the Intergovernmental Panel on Climate Change (Edenhofer, O., Pichs-Madruga, R., Sokona, Y., Farahani, E., Kadner, S., Seyboth, K., Adler, A., Baum, I., Brunner, S., Eickemeier, P., Kriemann, B., Savolainen, J., Schlömer, S., von Stechow, C., Zwickel, T. \& Minx, J.C. [eds.]). Cambridge University Press, Cambridge, United Kingdom and New York, NY, USA.

Soinne, H., Hyväluoma, J., Ketoja, E. \& Turtola, E. 2016. Relative importance of organic carbon, land use and moisture conditions for the aggregate stability of post-glacial clay soils. Soil and Tillage Research Volume 158: 1-9. https://doi.org/10.1016/j.still.2015.10.014

Soon, Y.K. \& Arshad, M.A. 2005. Tillage and liming effects on crop and labile soil nitrogen in an acid soil. Soil and Tillage Research 80: 23-33. https://doi.org/10.1016/j.still.2004.02.017

Sosulski, F.W. \& Imafidon, G.I. 1990. Amino acid composition and nitrogen-to-protein conversion factors for animal and plant foods. Journal of Agricultural and Food Chemistry 38: 1351-1356. https://doi.org/10.1021/jf00096a011

Steffen, W., Richardson, K., Rockström, J., Cornell, S.E., Fetzer, I., Bennett, E., Biggs, R., Carpenter, S.R., de Vries, W., de Wit, C.A., Folke, C., Gerten, D., Heinke, J., Mace, G.M., Persson, L.M., Ramanathan, V., Reyers, B. \& Sörlin, S. 2015. Planetary boundaries: Guiding human development on a changing planet. Science 347:1259855. https://doi.org/10.1126/science.1259855

Stoate, C., Boatman, N.D., Borralho, R.J., Carvalho, C.R., Snoo, G.R. \& Eden, P. 2001. Ecological impacts of arable intensification in Europe. Journal of Environmental Management 63: 337-365. https://doi.org/10.1006/jema.2001.0473

Vagstad, N., Broch-Due, A. \& Lyngstad, I. 2001. Direct and residual effects of pulp and paper mill sludge on crop yield and soil mineral N. Soil Use and Management 17: 173-178. https://doi.org/10.1079/SUM200172

Valkama, E., Salo, T., Esala, M. \& Turtola, E. 2013. Grain quality and N uptake of spring cereals as affected by nitrogen fertilization in northern conditions: a meta-analysis. Agricultural and Food Science 22: 208-222. https://doi.org/10.23986/afsci.7448

Vance, E.D. 2000. Recycling paper mill by-products on forest lands: By-product composition, potential applications, and industry case studies. In: Henry, C.L., Harrison, R.B. \& Bastian, R.K. (eds.). The Forest Alternative: Principles and Practice of Residuals Use. College of Forest Resources, University of Washington, Seattle, Wa. p. 193-207.

Vinten, A.J.A., Davis, R., Castle, K. \& Baggs, E.M. 1998. Control of nitrate leaching from a nitrate vulnerable zone using paper mill waste. Soil Use and Management 14: 44-51. https://doi.org/10.1111/j.1475-2743.1998.tb00609.x

Vuorinen, J. \& Mäkitie, O. 1955. The method of soil testing in use in Finland. Agrogeological Publication 63:1-44.

Wezel, A., Soboksa, G., McClelland, S., Delespesse, F. \& Boissau, A. 2015. The blurred boundaries of ecological, sustainable, and agroecological intensification: A review. Agronomy for Sustainable Development: 35: 1283-1295.

https://doi.org/10.1007/s13593-015-0333-y

Wooding, A.R., Kavale, S., MacRitchie, F., Stoddard, F.L. \& Wallace, A. 2000. Effects of nitrogen and sulfur fertiliser on protein composition, mixing requirements, and dough strength of four wheat cultivars. Cereal Chemistry 77: 798-807. https://doi.org/10.1094/CCHEM.2000.77.6.798

Yang, S., Liu, J., Wu, J., Tan, H. \& Li, Y. 2013. Effects of Vinasse and Press Mud Application on the Biological Properties of Soils and Productivity of Sugarcane. Sugar Tech 15: 152. https://doi.org/10.1007/s12355-012-0200-y

Ziadi, N., Gagnon, B. \& Nyiraneza, J. 2013. Crop yield and soil fertility as affected by papermill biosolids and liming by-products. Canadian Journal of Soil Science 93: 319-328. https://doi.org/10.4141/cjss2012-129

Zibilske, L.M., Clapham, W.M. \& Rourke, R.V. 2000. Multiple applications of paper mill sludge in an agricultural system: soil effects. Journal of Environmental Quality 29: 1975-1981. https://doi.org/10.2134/jeq2000.00472425002900060034x 
Appendix 1. Details of the crop stand types, i.e. main plots, in the field experiment for pulp mill sludge

\begin{tabular}{|c|c|c|c|}
\hline \multirow[b]{2}{*}{ Stand type } & \multicolumn{3}{|c|}{$\begin{array}{l}\text { Species, varieties, sowing densities (viable seeds } \mathrm{m}^{-1} \text { or } \mathrm{kg} \mathrm{ha}^{-1} \text { ), sowing date - harvesting date of the } \\
\text { cereal and undersown and catch crops }\end{array}$} \\
\hline & Season 2015 & Season 2016 & Season 2017 \\
\hline Sole cereal & & $\begin{array}{l}\text { Spring wheat 'Anniina' } \\
650 \mathrm{~m}^{-1}+650 \mathrm{~m}^{-1} \\
7 \text { May(26 May) - } 31 \text { August } 2016\end{array}$ & $\begin{array}{l}\text { Spring oat 'Obelix' } \\
500 \mathrm{~m}^{-1} \\
10 \text { May - } 5 \text { September } 2017\end{array}$ \\
\hline Undersown cereal & $\begin{array}{l}\text { Ryegrass 'Meroa', } 20 \mathrm{~kg} \mathrm{ha}^{-1} \\
12 \text { May } 2015-31 \text { August } 2015\end{array}$ & 'Anniina' as the sole cereal & 'Obelix' as the sole cereal \\
\hline $\begin{array}{l}\text { Cereal with catch } \\
\text { crop }\end{array}$ & & $\begin{array}{l}\text { 'Anniina' as the sole cereal } \\
\text { and ryegrass 'Meroa',21.3 kg ha }{ }^{-1} \\
11 \text { September } 2015 \text { - } 31 \text { August } 2016\end{array}$ & 'Obelix' as the sole cereal \\
\hline
\end{tabular}

Appendix 2. Results of Tukey's pairwise post hoc tests comparing yields between different fertiliser treatments. The estimate shows the difference between the treatments when the mean of the treatment in the 2 nd column is subtracted from the mean of the treatment in the 1 st column.

\begin{tabular}{|c|c|c|c|c|c|c|c|}
\hline \multirow[t]{2}{*}{$\begin{array}{l}\text { Pair of fertiliser } \\
\text { compared }\end{array}$} & & \multicolumn{3}{|c|}{ Wheat (2016) } & \multicolumn{3}{|c|}{ Oat (2017) } \\
\hline & & Estimate & SE & $\mathrm{p}$ & Estimate & SE & $\mathrm{p}$ \\
\hline \multirow[t]{5}{*}{ Mineral } & CPMS A & 106.4 & 85.5 & 0.813 & -81.6 & 103.4 & 0.968 \\
\hline & CPMS B & 226.2 & 85.5 & 0.108 & -225.7 & 103.4 & 0.266 \\
\hline & LPMS A & 294.6 & 85.5 & $0.015 *$ & -173.6 & 103.4 & 0.553 \\
\hline & LPMS B & 183.9 & 85.5 & 0.282 & -149.7 & 103.4 & 0.698 \\
\hline & Zero-control & 811.4 & 87.5 & $0.000 * * *$ & 1225.7 & 103.4 & $0.000 * * *$ \\
\hline \multirow[t]{4}{*}{ Zero-control } & CPMS A & -705.0 & 87.5 & $0.000 * * *$ & -1307.3 & 103.4 & $0.000 * * *$ \\
\hline & CPMS B & -585.1 & 87.5 & $0.000 * * *$ & -1451.4 & 103.4 & $0.000 * * *$ \\
\hline & LPMS A & -516.8 & 87.5 & $0.000 * * *$ & -1399.3 & 103.4 & $0.000 * * *$ \\
\hline & LPMS B & -627.6 & 87.5 & $0.000 * * *$ & -1375.4 & 103.4 & $0.000 * * *$ \\
\hline \multirow[t]{3}{*}{ LPMS B } & CPMS A & -77.4 & 85.5 & 0.943 & 68.0 & 103.4 & 0.986 \\
\hline & CPMS B & 42.4 & 85.5 & 0.996 & -76.0 & 103.4 & 0.976 \\
\hline & LPMS A & 110.8 & 85.5 & 0.786 & -23.9 & 103.4 & 1.000 \\
\hline \multirow[t]{2}{*}{ CPMS B } & CPMS A & -119.9 & 85.5 & 0.726 & 144.1 & 103.4 & 0.731 \\
\hline & LPMS A & 68.4 & 85.5 & 0.966 & 52.1 & 103.4 & 0.996 \\
\hline LPMS A & CPMS A & -188.2 & 85.5 & 0.258 & 92.0 & 103.4 & 0.947 \\
\hline
\end{tabular}

